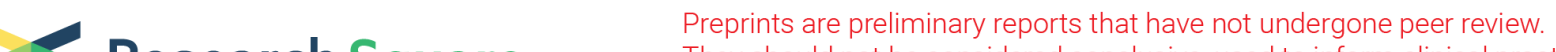 $\begin{array}{ll}\text { Research Square } & \text { They should not be considered conclusive, used to inform clinical practice, } \\ \text { or referenced by the media as validated information. }\end{array}$
}

\section{Role of Zn And Polyaniline In Magnetic \\ Nanocomposites And Enhanced Arsenic Adsorption Capacity In Wastewater}

\section{Tran Minh Thi}

Van Duyn Elementary School

\section{Nguyen Mau Lam}

Hanoi Pedagogical University No 2

Do Khanh Tung

Vietnam Academy of Science and Technology

Nguyen Manh Nghia

Hanoi National University of Education

Duong Quoc Van

Hanoi National University of Education

\section{Vu Quoc Manh}

Thanh Do University

\section{Nguyen Thi Bich Viet}

Hanoi National University of Education

Duong Khanh Linh

Hanoi National University of Education

Nguyen Thuy Chinh

Vietnam Academy of Science and Technology

Thai Hoang

Vietnam Academy of Science and Technology

Quoc Trung Vu ( $\square$ trungvq@hnue.edu.vn )

Hanoi National University of Education https://orcid.org/0000-0003-4629-0958

\section{Research Article}

Keywords: adsorption ability, magnetization, infrared spectra, polyaniline/Fe0.90Zn0.10Fe204 nanocomposites

Posted Date: December 28th, 2021

DOI: https://doi.org/10.21203/rs.3.rs-1176740/v1 
License: (c) (i) This work is licensed under a Creative Commons Attribution 4.0 International License. Read Full License 


\section{Abstract}

Polyaniline/ $\mathrm{Fe}_{0.90} \mathrm{Zn}_{0.10} \mathrm{Fe}_{2} \mathrm{O}_{4}\left(\mathrm{PANI} / \mathrm{Zn}_{0.10} \mathrm{Fe}_{2.90} \mathrm{O}_{4}\right)$ nanocomposites were synthesized by a chemical method and an onsite polymerization method. XRD patterns showed that the $\mathrm{Zn}_{0.10} \mathrm{Fe}_{2.90} \mathrm{O}_{4}$ grain size about $12 \mathrm{~nm}$, while TEM image showed grain size from 10 to $20 \mathrm{~nm}$. The results of Raman spectra and DTA analyses showed that PANI participated in part of the PANI/ $Z \mathrm{n}_{0.10} \mathrm{Fe}_{2.90} \mathrm{O}_{4}$ nanocomposite samples. The grain size of PANI/ $\mathrm{Zn}_{0.10} \mathrm{Fe}_{2.90} \mathrm{O}_{4}$ samples measured by SEM was about $35-50 \mathrm{~nm}$. These results demonstrated the shell-core structures of the nanocomposite material. The magnetization measurements at room temperature showed that in 1250 Oe magnetic field, the saturation magnetic moment of PANI/ $\mathrm{Zn}_{0.10} \mathrm{Fe}_{2.90} \mathrm{O}_{4}$ samples decreased from 71.2 to $42.3 \mathrm{emu} / \mathrm{g}$ when the PANI concentration increased from $0 \%$ to $15 \%$. The surface area and porous structure of nanoparticles were investigated by the $B E T$ method at $77 \mathrm{~K}$ and a relative pressure $P / P_{0}$ of about 1 . The arsenic adsorption capacity of the PANI/Z $\mathrm{n}_{0.10} \mathrm{Fe}_{2.90} \mathrm{O}_{4}$ sample with the PANI concentration of $5 \%$ was better than that of $\mathrm{Fe}_{3} \mathrm{O}_{4}$ and $\mathrm{Zn}_{0.10} \mathrm{Fe}_{2.90} \mathrm{O}_{4}$ in a solution of $\mathrm{pH}$ 7. In the solution with $\mathrm{pH} \mathrm{P} 14$, the arsenic adsorption of magnetic nanoparticles was insignificant. Due to substitution of Fe ions by $\mathrm{Zn}$ transition metal and coating polyaniline, these materials could be reabsorbed and reused.

\section{Introduction}

Transition metal doped $\mathrm{Fe}_{3} \mathrm{O}_{4}$ magnetic nanomaterials attract attention of the scientists due to their wide applications, especially in water treatment or other environmental pollution monitoring [1-16]. Recently, $\mathrm{Cd}, \mathrm{Cr}$, As removals were observed using the metal oxide hetero-structures, as meso-porous $\mathrm{MnO}_{2}, \mathrm{Al}_{2} \mathrm{O}_{3}$, $\mathrm{TiO}_{2}, \mathrm{CuO}, \mathrm{ZrO}_{2}[1,17-23]$. The major backwards of using these oxides are the difficulties in their recovery and thus leaving their residuals in the environment. In this circumstance, magnetic nanoporous materials are considered as potential candidates for heavy metal removal because it's simple and efficient to recover them from the solution by means of external magnetic field.

Due to the rapid oxidation of $\mathrm{Fe}_{3} \mathrm{O}_{4}$ into $\mathrm{Y}-\mathrm{Fe}_{2} \mathrm{O}_{3}$ in air as well as its decreased magnetization, large numbers of studies have focused on improving the saturation magnetization and chemical stability of the magnetic nanomaterials for effective heavy metal ion adsorption [10, 19, 24-29]. Two research directions are being considered: (i) partial replacement of divalent metal ions for $\mathrm{Fe}^{2+}$ ions, and (ii) coating of magnetic nanoparticles by polymers.

The unit cell of $\mathrm{Fe}_{3} \mathrm{O}_{4}$ consists of two kinds of interstitial sites denoted as tetrahedral A-site $\left(\mathrm{Fe}^{3+}\right)$ and octahedral B-site $\left(\mathrm{Fe}^{2+}: \mathrm{Fe}^{3+}=1: 1\right)[19,25]$. The divalent metal ions like $\mathrm{Mn}^{2+}, \mathrm{Cu}^{2+}$ and $\mathrm{Zn}^{2+}$ are usually substituted into $B$-site to form inverse spinel ferrites such as $\mathrm{Fe}_{1-x} \mathrm{Mn}_{x} \mathrm{Fe}_{2} \mathrm{O}_{4}$ (with $\mathrm{x}=0 \div 0.15$ or 0.5 ) [27, 30], $\mathrm{Fe}_{1-x} \mathrm{Cu}_{x} \mathrm{Fe}_{2} \mathrm{O}_{4}$ (with $\mathrm{x}=0 \div 0.15$ ) [30], $\mathrm{Ni}_{x} \mathrm{Fe}_{3-\mathrm{x}} \mathrm{O}_{4}$ sample system $(\mathrm{x}=0.04 ; 0.06 ; 0.11)$ [25], or $\mathrm{Ni}_{1-x} \mathrm{Zn}_{x} \mathrm{Fe}_{2} \mathrm{O}_{4}$ sample system ( $x=0,0.5$ and 1$)$ [26]. However, $\mathrm{Fe}_{1-\mathrm{x}} \mathrm{Zn}_{\mathrm{x}} \mathrm{Fe}_{2} \mathrm{O}_{4}(\mathrm{x}=0 ; 0.2 ; 0.4 ; 0.5)$ thin 
films or nanopowders with pretty large magnetization were confirmed by the partial substitutions of $\mathrm{Zn}^{2+}$ ions into A-sites [19, 31].

Magnetic nanoparticles are studied to treat heavy metals, weak-acid oxyanion contaminants or dyes in the environment [32-35]. In particular, the coating of magnetic nanoparticles by polymers are also studied to protect the chemical physical properties of magnetic nanoparticles simultaneously ensuring the recovery and reuse of the adsorbent materials $[35,36]$.

Polyaniline (PANI) is well-known as a conductive polymer whose high electrical conductivity has been discovered and is expected to play an increasingly significant role in many fields due to its easy synthesis, physicochemical stability, and simple doping chemistry. In recent, the substitution of $\mathrm{Mn}, \mathrm{Cu}$, $\mathrm{Zn}$ elements for Fe ions and the coating of magnetic nanoparticles by poly(1-naphthylamine), polyvinyl pyrrolidone have been studied $[30,31,36]$ in order to stabilize the physicochemical properties and enhance their applicability. In this work, we discuss the synthesis, magnetic properties, microstructure of $\mathrm{PANI} / \mathrm{Fe}_{0.90} \mathrm{Zn}_{10} \mathrm{Fe}_{2} \mathrm{O}_{4}$ nanocomposites with different mass ratios of $\mathrm{PANI} / \mathrm{Fe}_{0.90} \mathrm{Zn}_{0.10} \mathrm{Fe}_{2} \mathrm{O}_{4}$ and the

$\mathrm{Zn}^{2+}$ substitution for $\mathrm{Fe}^{2+}$. Besides, the effect of PANI content on the arsenic adsorption ability in aqueous at different $\mathrm{pH}$ values as well as the desorption/re-adsorption capacities of the magnetic nanomaterials are also discussed.

\section{Experimentals}

\subsection{Chemical and apparatus}

All chemicals are at analytical grade: $\mathrm{FeCl}_{3} \cdot 6 \mathrm{H}_{2} \mathrm{O}, \mathrm{Na}_{2} \mathrm{SO}_{3}, 25 \% \mathrm{NH}_{3}, \mathrm{Zn}\left(\mathrm{CH}_{3} \mathrm{COO}\right)_{2} \cdot 2 \mathrm{H}_{2} \mathrm{O}, \mathrm{NaOH}, \mathrm{HCl}$, acetone 99\%, isopropanol (IPA). As(III) solutions in which the As(III) content of 106 ppb, 10 times higher than allowed levels regulated by the World Health Organization (WHO) were prepared from $\mathrm{As}_{2} \mathrm{O}_{3}$. Labconco Freeze Concentrator (USA) was used for material drying in vacuum. The structure and morphology of the samples were investigated by XRD patterns (D5005, Bruker), TEM (JEOL5410), SEM (S4800), IR Prestige -21 and thermal gravimetric analysis by DTG- $60 \mathrm{H}$. Meanwhile the magnetization was measured by vibrating sample magnetometer (VSM $8600 \mathrm{~S}$ ) and the mesopores structure of samples was observed by TriStar 3000 V6.07A with TriStar 3000 V6.08 software. The Flame-Atomic Absorption Spectrophotometer (F-AAS 6300 Shimadzu) was used to determine the arsenic content in the solutions before and after using adsorbent magnetic nanomaterials.

\subsection{Synthesis of $\mathrm{Fe}_{0.90} \mathrm{Zn}_{0.10} \mathrm{Fe}_{2} \mathrm{O}_{4}$ by chemical method}

A detailed synthesis procedure was described in our previous paper [30,31]. The chemical reactions occur during the synthesized process of $\mathrm{Fe}_{3} \mathrm{O}_{4}$ :

$2 \mathrm{FeCl}_{3}+\mathrm{Na}_{2} \mathrm{CO}_{3}+\mathrm{H}_{2} \mathrm{O} \rightarrow 2 \mathrm{FeCl}_{2}+\mathrm{Na}_{2} \mathrm{SO}_{4}+2 \mathrm{HCl}$

$\mathrm{FeCl}_{3}+\mathrm{FeCl}_{2}+8 \mathrm{NH}_{3}+4 \mathrm{H}_{2} \mathrm{O} \rightarrow \mathrm{Fe}_{3} \mathrm{O}_{4} \exists+8 \mathrm{NH}_{4} \mathrm{Cl}$ 
To get $\mathrm{Fe}_{2.9} \mathrm{Zn}_{0.10} \mathrm{O}_{4}$ (signed $\mathrm{Fe}_{0.90} \mathrm{Zn}_{0.10} \mathrm{Fe}_{2} \mathrm{O}_{4}$ ) nanoparticles, the $\mathrm{FeCl}_{3} \cdot 6 \mathrm{H}_{2} \mathrm{O}, \mathrm{Zn}\left(\mathrm{CH}_{3} \mathrm{COO}\right)_{2} \cdot 4 \mathrm{H}_{2} \mathrm{O}$ solutions containing $\mathrm{Fe}^{3+}$ and $\mathrm{Zn}^{2+}$ with nominal $\mathrm{Zn}$ atom content of 0.10 were mixed with a $\mathrm{Na}_{2} \mathrm{SO}_{3}$ solution. These mixed solutions were stirred until they turned to yellow in color. Then, the $\mathrm{NH}_{3}$ solution was added dropwise until the $\mathrm{pH}$ was 10 . The solution was kept stirring for 30 minutes until it turned to black. These magnetic grains were separated from the mixture solution using external magnets, and then filtered, washed with distilled water. Finally, these materials were desiccated at $50^{\circ} \mathrm{C}$ for 48 hours and finely grinded to obtain $\mathrm{Fe}_{0.90} \mathrm{Zn}_{0.10} \mathrm{Fe}_{2} \mathrm{O}_{4}$ nanoparticles.

\subsection{Synthesis of $\mathrm{PANI} / \mathrm{Fe}_{0.90} \mathrm{Zn}_{0.10} \mathrm{Fe}_{2} \mathrm{O}_{4}$ nanocomposites}

The synthesis of PANI/ $/ \mathrm{ee}_{0.90} \mathrm{Zn}_{0.10} \mathrm{Fe}_{2} \mathrm{O}_{4}$ nanocomposite by in-situ polymerization method was briefly described as follow:

Step 1: a calculated amount of $\mathrm{Fe}_{0.90} \mathrm{Zn}_{0.10} \mathrm{Fe}_{2} \mathrm{O}_{4}$ was added in $60 \mathrm{~mL}$ of distilled water, followed by 40 $\mathrm{mL}$ of IPA, aniline and well stirred for 60 minutes (mixture A).

Step 2: a stoichiometric amount of $\left(\mathrm{NH}_{4}\right)_{2} \mathrm{~S}_{2} \mathrm{O}_{8}$ solution, with the monomer/oxidizing agent molar ratio of $1: 1.5$, was added dropwise into mixture $A$ to obtain a black blue mixture (mixture $B$ ) which was allowed to stir for 2 hours with an exothermal reaction.

Step 3 : Filter the mixture using external magnet, then the obtained solid was dried by Labconco Freeze concentrator for 5 hours at $1 \mathrm{mPa}$ and temperature of $40^{\circ} \mathrm{C}$. The nanocomposites with $0 \%, 5 \%, 10 \%$ and $15 \%$ mass ratios of $\mathrm{PANI} / \mathrm{Fe}_{0.90} \mathrm{Zn}_{0.10} \mathrm{Fe}_{2} \mathrm{O}_{4}$ were coded by $\mathrm{S}_{0}, \mathrm{~S}_{1}, \mathrm{~S}_{2}$ and $\mathrm{S}_{3}$ as represented in Table 1 .

Table 1

Mass ratios of PANI/Fe $e_{0.90} \mathrm{Zn}_{0.10} \mathrm{Fe}_{2} \mathrm{O}_{4}$ in $\mathrm{S}_{0}, \mathrm{~S}_{1}, \mathrm{~S}_{2}$,

$\mathrm{S}_{3}$ samples

\begin{tabular}{|lcccc|}
\hline Sample & $\mathbf{S}_{\mathbf{0}}$ & $\boldsymbol{S}_{\mathbf{1}}$ & $\boldsymbol{S}_{\mathbf{2}}$ & $\boldsymbol{S}_{\mathbf{3}}$ \\
\hline $\mathrm{Fe}_{0.90} \mathrm{Zn}_{0.10} \mathrm{Fe}_{2} \mathrm{O}_{4}$, (in g) & 20 & 20 & 20 & 20 \\
PANI (in g) & 0 & 1.0 & 2.0 & 3.0 \\
\hline
\end{tabular}

\subsection{The evaluation of arsenic adsorption}

The evaluation of arsenic adsorption capacity of the samples was performed at room temperature. The experiment was conducted by adding $0.01 \mathrm{~g}$ of samples $\left(\mathrm{S}_{0}, \mathrm{~S}_{1}, \mathrm{~S}_{2}\right.$ and $\left.\mathrm{S}_{3}\right)$ into $\mathrm{As}$ (III) solutions of initial content of $106 \mathrm{ppb}$. Each mixture was then allowed to stir in 20 minutes for a complete adsorption. The arsenic contents before and after adsorption were analyzed by F-AAS.

\section{Results And Discussion}

\subsection{Structure, morphology and physical properties}


In Fig. 1, the diffraction peaks of (220), (311), (400), (442), (511), (440) of the $\mathrm{Fe}_{0.90} \mathrm{Zn}_{0.10} \mathrm{Fe}_{2} \mathrm{O}_{4}\left(\mathrm{~S}_{0}\right)$ sample were completely fitted with the standard diffraction pattern of $\mathrm{Fe}_{3} \mathrm{O}_{4}$ as in our previous publication [31], and demonstrated the centered face cubic structure. Similarly, the XRD patterns of $S_{2}$ and $\mathrm{S}_{3}$ samples showed the same diffraction peaks as that of $\mathrm{Fe}_{3} \mathrm{O}_{4}$ sample, which proved that the $\mathrm{Zn}^{2+}$ doping as well as the addition of polymer did not affect the crystal structure of materials. Thus, Fig. 1 presented typical $S_{2}$ and $S_{3}$ samples of all samples with different PANI amount. From diffraction conditions, $2 \mathrm{~d} \sin \theta=n \lambda$, the lattice constants of the nanoparticles in the $\mathrm{Fe}_{0.90} \mathrm{Zn}_{0.10} \mathrm{Fe}_{2} \mathrm{O}_{4}, \mathrm{~S}_{2}$ and $\mathrm{S}_{3}$ samples were the same with $a=8.376 A^{0}$ which was determined by the relation:

$a=d_{h k l} \sqrt{h^{2}+k^{2}+l^{2}}$; where $\mathrm{d}_{\mathrm{hkl}}$ is the distance of the lattice planes of $\mathrm{Fe}_{0.90} \mathrm{Zn}_{0.10} \mathrm{Fe}_{2} \mathrm{O}_{4}$. Because PANI polymer is an amorphous material and does not affect the crystal structure of $\mathrm{Fe}_{0.90} \mathrm{Zn}_{0.10} \mathrm{Fe}_{2} \mathrm{O}_{4}$, thus the calculated particle size from XRD patterns is also the particle size for $S_{1}, S_{2}$ and $S_{3}$ samples. Thus, the average crystal particle sizes of $\mathrm{Fe}_{0.90} \mathrm{Zn}_{0.10} \mathrm{Fe}_{2} \mathrm{O}_{4}$ in all $\mathrm{S}_{0}, \mathrm{~S}_{1}, \mathrm{~S}_{2}$ and $\mathrm{S}_{3}$ samples were about $12 \mathrm{~nm}$, calculated by the formula $D=0.9 \lambda / \beta \cos \theta\left(\lambda=1.5416 \mathrm{~A}^{0} ; \beta\right.$ : full width at haft maximum of diffraction line). In Fig. 2a, the TEM image of $S_{0}$ sample shows the grain sizes of ca. $10-18 \mathrm{~nm}$, however, Fig. $2 b$ show the agglomeration in $\mathrm{S}_{1}$ sample with grain size of $c a .40-50 \mathrm{~nm}$. Meanwhile, in SEM images in Fig. $2 c$ and Fig. $2 d$, the grain sizes in $S_{2}, S_{3}$ samples were about $35-50 \mathrm{~nm}$ and $40-50 \mathrm{~nm}$, respectively. This result proved that PANI prevented the agglomeration of the magnetic nanoparticles. Simultaneously, it also suggested that $S_{1}, S_{2}$ and $S_{3}$ samples have the core-shell structures created by the polymerization of $\mathrm{PANl}$ at the surface of $\mathrm{Fe}_{0.90} \mathrm{Zn}_{0.10} \mathrm{Fe}_{2} \mathrm{O}_{4}$ nanoparticles.

\subsection{FTIR spectra analyses}

Fig. 3a shows strong absorbed peaks of PANI in the region from 1149 to $1570 \mathrm{~cm}^{-1}$ with the highest intensity at $1149 \mathrm{~cm}^{-1}$ peak. These peaks were attributed to the absorption of the $\mathrm{C}=\mathrm{C}$ (aromatic), C-N $\mathrm{N}^{+}, \mathrm{C}$ $=\mathrm{N}$ groups of the PANI [37]. Meanwhile, Fig. $3 \mathrm{~b}$ shows the strong adsorbed peak of $\mathrm{Fe}_{0.90} \mathrm{Zn}_{0.10} \mathrm{Fe}_{2} \mathrm{O}_{4}$ at $570 \mathrm{~cm}^{-1}$, and Fig. $3 \mathrm{c}$ shows some characteristic peaks of both samples.

The infrared spectrum of $S_{2}$ (Fig. 3c) showed the absorption peaks appeared in the range of 1134 to $1173 \mathrm{~cm}^{-1}$ with much stronger intensity than some peaks of $\mathrm{Fe}_{0.90} \mathrm{Zn}_{0.10} \mathrm{Fe}_{2} \mathrm{O}_{4}$. This suggests that PANI is present in the component of $\mathrm{S}_{2}$.

\subsection{TGA and DTG analyses}

TGA curve in Fig. $4 a$ showed that at temperature range below $80{ }^{\circ} \mathrm{C}$, the volume reduction of PANI was due to the evaporation of water, corresponding to $13 \%$ with a sharp endothermic peak at $45^{\circ} \mathrm{C}$ in the DTG curve. From $80-210{ }^{\circ} \mathrm{C}$, the sample volume stays almost unchanged. However, from $210-320^{\circ} \mathrm{C}$, the reduction of sample volume in TGA curve happened due to the decomposition of PANI to form monomers, oligomers, dimers and trimers corresponding to a sharp endothermic peak at $292{ }^{\circ} \mathrm{C}$ in the 
DTG curve. At temperature higher than $320^{\circ} \mathrm{C}$, the weight loss caused by the thermal decomposition of the oligomers, dimers, trimers. This led to a complete decomposition of PANI at above $600{ }^{\circ} \mathrm{C}$.

TGA curve of typical $\mathrm{S}_{2}$ sample (for $\mathrm{S}_{1}$ and $\mathrm{S}_{3}$ ) in Fig. $4 \mathrm{~b}$ also showed that at temperature range below 80 ${ }^{0} \mathrm{C}$, the $8.6 \%$ reduction of sample volume due to water evaporation corresponding to a sharp endothermic peak at $45.2{ }^{\circ} \mathrm{C}$ in the DTG curve. However, from $100-300{ }^{\circ} \mathrm{C}$ in the TGA curve, the $3.3 \%$ reduction of sample volume may be happened due to the decomposition of the residual monomers and oligomers in the sample. From $300-600{ }^{\circ} \mathrm{C}$, the thermal decomposition of the oligomers, dimers, trimers caused a small and broad endothermic peak at $395^{\circ} \mathrm{C}$ in the DTG curve. Thus, the sample mass remained only $30 \%$ at $600{ }^{\circ} \mathrm{C}$. Because PANI is quite stable in the temperature range below $150{ }^{\circ} \mathrm{C}$, it can be seen from above results that the $S_{1}, S_{2}$ and $S_{3}$ nanocomposites have been successfully synthesized and the presence of PANI in these samples has improved the thermal stability of PANI-coated $\mathrm{Fe}_{0.90} \mathrm{Zn}_{0.10} \mathrm{Fe}_{2} \mathrm{O}_{4}$ in temperature range below $150{ }^{\circ} \mathrm{C}$.

\subsection{Magnetization and chemical instability}

In the air environment, $\mathrm{Fe}_{3} \mathrm{O}_{4}$ is easy to be oxidized to give $\mathrm{y}-\mathrm{Fe}_{2} \mathrm{O}_{3}$. Thus, the saturation magnetization of new synthesized $\mathrm{Fe}_{3} \mathrm{O}_{4}$ samples decreased from $63.13 \mathrm{emu} / \mathrm{g}$ to $56 \mathrm{emu} / \mathrm{g}$ after 2 months of synthesis [30]. This phenomenon related the oxidation of $\mathrm{Fe}_{3} \mathrm{O}_{4}$ into $\mathrm{y}-\mathrm{Fe}_{2} \mathrm{O}_{3}$ due to oxygen in air according to the equation:

$4 \mathrm{Fe}_{3} \mathrm{O}_{4}+\mathrm{O}_{2} \rightarrow 6 \mathrm{Fe}_{2} \mathrm{O}_{3}$

The change of magnetization and chemical instability of the $\mathrm{Fe}_{3} \mathrm{O}_{4}$ sample led to a limitation of their application ability. Thus, the $\mathrm{Zn}^{2+}$ substitution for $\mathrm{Fe}^{2+}$ ions and the polymer coating outside nanoparticles are the optimal methods to stabilize chemical properties and magnetization of $\mathrm{Fe}_{0.90} \mathrm{Zn}_{0.10} \mathrm{Fe}_{2} \mathrm{O}_{4}$ material.

For the $\mathrm{Fe}_{0.90} \mathrm{Zn}_{0.10} \mathrm{Fe}_{2} \mathrm{O}_{4}$ sample in Fig. 5, the saturation magnetization of $71.5 \mathrm{emu} / \mathrm{g}$ is higher than that of $\mathrm{Fe}_{3} \mathrm{O}_{4}$ [36] ( $c a .63 \mathrm{emu} / \mathrm{g}$ ). Unlike the replacement of transition metal elements $\mathrm{Cu}, \mathrm{Mn}, \mathrm{Ni}$ for Fe ${ }^{2+}$ into octahedral B-site [24, 25, 27], preferably the replacement of $\mathrm{Zn}^{2+}$ ions for $\mathrm{Fe}^{3+}$ at tetrahedron A-site occurs $[19,26]$, simultaneously $\mathrm{Fe}^{2+}$ amount at the octahedral B-site gives electrons to become $\mathrm{Fe}^{3+}$ in order to balance the charge of cell network $[19,26]$. Since the ionic radius of the $\mathrm{Fe}^{3+}$ ion is $0.64 \AA$ and the ionic radius of the $Z n^{2+}$ ion is $0.74 \AA$, the substitution of $Z n$ with content $x=0.10$ caused a slight increasing of the lattice constant $\left(a=8.386 A^{0}\right)$ in comparison with $\mathrm{Fe}_{3} \mathrm{O}_{4}\left(a=8.3760 A^{0}\right)[30,36]$. This was due to the $\mathrm{Zn}^{2+}$ size larger than $\mathrm{Fe}^{3+}$. This substitution and transformation caused a change in ions distribution of the network subdivisions to $\left[\mathrm{Zn}_{\mathrm{x}}{ }^{2+} \mathrm{Fe}_{1-\mathrm{x}}{ }^{3+}\right]_{\mathrm{A}}\left[\mathrm{Fe}^{3+} \mathrm{Fe}_{\mathrm{x}}{ }^{3+} \mathrm{Fe}_{1-\mathrm{x}}{ }^{2+}\right]_{\mathrm{B}}$.

The magnetic moment depends on the content of $x$ that is considered due to the decision of spin direction of $\mathrm{Fe}_{x}{ }^{3+}$ in B-site, but do not depends on the presence of non-magnetic $\mathrm{Zn}$ ions [19, 31]. This has 
been clearly explained in our recent publication [31]. Therefore, the saturation magnetization of $\mathrm{Fe}_{0.90} \mathrm{Zn}_{0.10} \mathrm{Fe}_{2} \mathrm{O}_{4}$ is higher than $\mathrm{Fe}_{3} \mathrm{O}_{4}[30,31]$.

On the other hand, the saturation magnetizations of $S_{1}, S_{2}$ and $S_{3}$ samples decreased from $65 \mathrm{emu} / \mathrm{g}$ to $43 \mathrm{emu} / \mathrm{g}$ when the non-magnetic PANI content increased from 5-15\% (Table 2). However, due to the PANI coating, the magnetization of nanocomposite materials is more stable over time.

Table 2

Lattice constant, grain size, Ms of $S_{0}, S_{1}, S_{2}$ and $S_{3}$

\begin{tabular}{|llllll|}
\hline & Lattice constant $\left(A^{0}\right)$ & $D_{\text {x-ray }}(n m)$ & $D_{\text {TEM }}(n m)$ & $D_{\text {SEM }}(n m)$ & Ms (Oe) \\
\hline$S_{0}$ & 8.385 & 11.81 & $10-18$ & & 71.5 \\
\hline$S_{1}$ & & & & $40-50$ & 65 \\
\hline$S_{2}$ & 8.386 & 11.80 & & $35-50$ & 53 \\
$S_{3}$ & 8.386 & 11.81 & & $40-50$ & 43 \\
\hline
\end{tabular}

\subsection{Adsorption kinetic, porous properties and arsenic adsorption ability}

The adsorption kinetic of $S_{0}, S_{1}, S_{2}$ and $S_{3}$ nanocomposites can be explained $[30,36]$ by the relation of adsorption ability based on the inelastic exchange interaction between specific surface area of nanoparticles and adsorbed materials. The surface and structure of nanoparticle mesopores were studied by the nitrogen adsorption-desorption isotherms of $0.54 \mathrm{~g}$ for $\mathrm{S}_{0}, \mathrm{~S}_{1}, \mathrm{~S}_{2}$ and $\mathrm{S}_{3}$ samples at $77 \mathrm{~K}[30,36]$.

Collision of $\mathrm{N}_{2}$ gas molecules with nanoparticles is considered to be inelastic, so that the $\mathrm{N}_{2}$ gas molecules remain in contact with the nanoparticles for a time before returning to the gas phase. This time delay is taken as responsible for the phenomenon of adsorption that demonstrated by equation: $P / V_{a}\left(P_{0}-P\right)=\left(1 / V_{m}\right)\left(P / P_{0}\right)$ [38]. Here, $V_{a}$ is the quantity of $N_{2}$ gas adsorbed at pressure $P$ and $V_{m}$ is the quantity of gas adsorbed when the entire surface is covered with a mono-molecular layer. The $\mathrm{N}_{2}$ adsorption-desorption isotherm curves of $S_{0}$ and $S_{1}$ samples at $77 \mathrm{~K}$ were presented in Fig. 6 . It can be clearly seen that the adsorption and desorption ability of $S_{1}$ sample is higher than that of $S_{0}$. By the BET (Brunauer, Emmett, and Taller) theory [38], the pore size distribution at relative pressure $P / P_{0} \approx 1$ and the specific surface area at low $P / P_{0}$ were calculated as shown in Table 3. 
Table 3

Porous properties and maximum arsenic adsorption ability

\begin{tabular}{|c|c|c|c|}
\hline Sample & $\begin{array}{l}\text { BET pore size }(\mathrm{nm}) \\
\text { at } \mathrm{P} / \mathrm{P}_{0} \approx 1\end{array}$ & $\begin{array}{l}\text { BET specific surface area } \\
\pm 0.02\left(\mathrm{~m}^{2} / \mathrm{g}\right) \text { at } \mathrm{P} / \mathrm{Po}=0.294\end{array}$ & $\begin{array}{l}\text { Maximum adsorption capacity } \\
\mathrm{q}_{\max }(\mathrm{mg} / \mathrm{g})\end{array}$ \\
\hline $\mathrm{S}_{0}$ & $9.16 \pm 0.02$ & $64.83 \mathrm{~m}^{2} / \mathrm{g}$ & $41.49 \pm 0.02$ \\
\hline $\mathrm{S}_{1}$ & $7.88 \pm 0.05$ & $105.89 \mathrm{~m}^{2} / \mathrm{g}$ & $43.48 \pm 0.03$ \\
\hline $\mathrm{S}_{2}$ & $8.42 \pm 0.03$ & $98.25 \mathrm{~m}^{2} / \mathrm{g}$ & $40.06 \pm 0.02$ \\
\hline $\mathrm{S}_{3}$ & $8.36 \pm 0.04$ & $99.67 \mathrm{~m}^{2} / \mathrm{g}$ & $34.48 \pm 0.03$ \\
\hline
\end{tabular}

\subsection{Arsenic adsorption ability}

In order to study As adsorption ability of the nanoparticles, the effects of $\mathrm{pH}$ in environment and As maximum adsorption capacity also investigate at room temperature.

Effects of $\mathrm{pH}$ to arsenic adsorption

To study the $\mathrm{pH}$ effect on the adsorption ability of the nanocomposites, the As(III) solutions with different $\mathrm{pH}$ in range of 1-14 were prepared. The As(III) adsorption results were presented in Fig. 7. It can be seen from Fig. 7 that the remaining arsenic content was a function of the $\mathrm{pH}$. For all nanocomposite samples, the arsenic adsorption capacity increased as the $\mathrm{pH}$ was increased from 1 to 7 . Then, the adsorption capacity decreased as the $\mathrm{pH}$ was increased above 7. The highest adsorption capacities were obtained in the range of $\mathrm{pH}$ 5-9. In both strong acidic and basic solution, the adsorption capacity decreased.

This trend can be explained by the speciation of arsenic (III) at different $\mathrm{pH}$ media and the surface charge status of the nanocomposites [39] in strong acidic environment. The surface of nanocomposites will be negatively charged at $\mathrm{pH}$ higher than $\mathrm{pH}_{\mathrm{pzc}}(\sim 7)$. Meanwhile, in neutral media, the un-charge in surface of nanocomposites and $\mathrm{As}(\mathrm{III})$ occurs mostly in neutral state $\left(\mathrm{H}_{3} \mathrm{AsO}_{3}\right.$ at $\mathrm{pH}$ below 9.2) [40], so at pH 7, the highest As(III) adsorption occurred, due to the electrostatic interaction is not feasible under this condition. Therefore, the As(III) adsorption was controlled by the surface complexation rather than the electrostatic interactions. Similar results were observed with other magnetic nanocomposites as reported earlier [39, 40].

When the pH elevates, As(III) exists mainly in form of $\mathrm{H}_{2} \mathrm{AsO}_{3}{ }^{-}, \mathrm{HAsO}_{3}{ }^{2-}$ and $\mathrm{AsO}_{3}{ }^{3-}$ anions while the surface charge of the nanoparticles is negative. Thus, the sharp decrease in the arsenic adsorption capacity at $\mathrm{pH}$ range of 11-14 is likely due to the electrostatic repulsion between the negatively charged surface of the nanocomposites and the deprotonated anionic arsenic. At extreme high pH 14, due to strong electrostatic repulsive force, the material has depicted no arsenic adsorption ability. 
Moreover, at very low pH levels (1-2), a decomposition of the $\mathrm{Fe}_{0.90} \mathrm{Zn}_{0.10} \mathrm{Fe}_{2} \mathrm{O}_{4}$ nanocomposites was observed proving by the presence of iron and zinc in the solution. In neutral and alkaline media, the nanocomposites were stable with no iron and zinc ions detected in the solution. Thus, it's suggested that the de-adsorption process of $S_{0}, S_{1}, S_{2}$ and $S_{3}$ should be conducted in solution at $\mathrm{pH} 14$.

As above analyzed results, the best As adsorption occurs in a neutral environment (pH7), where the inelastic exchange interaction takes place, which has the source of the Van der Waal interaction between the magnetic nanoparticles and adsorbent. Thus, maximum arsenic adsorption capacity was investigated by the Langmuir isotherm mode at $300 \mathrm{~K}$ in environment with $\mathrm{pH} 7$.

Maximum arsenic adsorption capacity

Equilibrium time of $\mathrm{As}(\mathrm{III})$ adsorption was analyzed by measuring the remaining arsenic content in solution $\mathrm{pH}$ 7. As shown in Fig. 8, the arsenic contents remain in the equilibrium state when the adsorption time is 20 minutes at room temperature. The maximum arsenic adsorption capacity $q_{\max }$ of unit volume of adsorbent $(\mathrm{mg} / \mathrm{g})$ is calculated by the Langmuir isotherm equation at $\mathrm{pH} 7$ and $300 \mathrm{~K}[6$, $10,17]$ with the first order linear relation:

$\frac{C_{f}}{q}=\frac{1}{q_{\max }} C_{f}+\frac{1}{b \cdot q_{\max }}$

where $C_{f}$ : the remaining arsenic content $(\mathrm{mg} / \mathrm{L})$ at equilibrium; $\mathrm{q}$ : the arsenic adsorption ability at equilibrium for a unit volume of adsorbent $(\mathrm{mg} / \mathrm{g})$; b: constants attributed to the interaction of the adsorbent and adsorbed compounds.

The calculated values of $q_{\max }$ for $S_{0}, S_{1}, S_{2}$ and $S_{3}$ are presented in Table 3.

As in Table 3, the arsenic adsorption capability of the materials, $q_{\max }$ of $S_{1}$ was better than that of $S_{0}$ $\left(\mathrm{Fe}_{0.90} \mathrm{Zn}_{0.10} \mathrm{Fe}_{2} \mathrm{O}_{4}\right)$ sample and $\mathrm{Fe}_{3} \mathrm{O}_{4}$, that reported in [36] with the same condition. The results in Table 2 also are in good agreement with those discussed in Fig. 8.

\section{Conclusion}

The PANI/ $\mathrm{Fe}_{0.90} \mathrm{Zn}_{0.10} \mathrm{Fe}_{2} \mathrm{O}_{4}$ nanocomposite materials were successfully synthesized with different mass ratios. These nanocomposite materials with core-shell structure have high saturated magnetic moments and high specific surface area that contribute to its high capability of adsorbing arsenic (III) in aqueous solutions. The $\mathrm{pH} 7$ and 20 -minute adsorption time are suitable factors for an effective adsorption process. The sample $S_{1}$ (PANI $5 \%$ mass ratio) with As adsorption capacity $\left(q_{\max }=43.48 \mathrm{mg} / \mathrm{g}\right.$ ) is highest than that of $\mathrm{S}_{0}, \mathrm{~S}_{2}, \mathrm{~S}_{3}$ samples and $\mathrm{Fe}_{3} \mathrm{O}_{4}$ nanoparticles. Due to the improving of saturation magnetization and chemical stability of nanomaterials, this work suggests the ability for heavy metal ion adsorption and the desorption in strong alkaline solution, then the materials could reabsorb for further trials. 


\section{Declarations}

\section{FUNDING}

This research did not receive any specific grant from funding agencies in the public, commercial, or not-for-profit sectors.

\section{AUTHOR STATEMENT}

No conflict of interest exits in the submission of this manuscript and manuscript is approved by all authors for publication.

\section{AUTHOR CONTRIBUTIONS}

Tran Minh Thi: Conceptualization, Writing - review \& editing; Nguyen Mau Lam: Formal analysis; Do Khanh Tung: Investigation, Methodology; Nguyen Manh Nghia: Validation; Duong Quoc Van: Formal analysis; Vu Quoc Manh: Writing - original draft; Nguyen Thi Bich Viet: Writing - original draft; Duong Khanh Linh: Data curation, Formal analysis; Nguyen Thuy Chinh: Investigation, Methodology; Thai Hoang: Writing - review \& editing and Vu Quoc Trung: Conceptualization; Writing - review \& editing, Project administration.

\section{References}

1. S. Prasanna, S. Mitsugu, K. Kenji, Y. Iwao, Growth conditions, structural and magnetic properties of $\mathrm{M} / \mathrm{Fe}_{3} \mathrm{O}_{4} / \mathrm{I}\left(\mathrm{M}=\mathrm{Al}, \mathrm{Ag}\right.$ and $\left.\mathrm{I}=\mathrm{Al}_{2} \mathrm{O}_{3}, \mathrm{MgO}\right)$ multilayers. Journal of Magnetic and Materials 247, 1-5 (2002)

2. L. Jun, B. Yuezhen, M. Masaru, Magnetic behavior of $\mathrm{Zn}$-doped $\mathrm{Fe}_{3} \mathrm{O}_{4}$ nanoparticles estimated in terms of crystal domain size. J. Phys. Chem. C 116, 134-143 (2012). https://doi.org/10.1021/jp207354s

3. J.F. Bertone, J. Cizeron, R.K. Wahi, J.K. Bosworth, V.L. Colvin, Hydrothermal synthesis of quartz nanocrystal. Nano Lett. 3, 655-659 (2003). https://doi.org/10.1021/nI025854r

4. A.I. Rusanov, Surface thermodynamic revisited. Surf. Sci. Rep. 58, 111 (2005). https://doi.org/10.1016/j.surfrep.2005.08.002

5. G. Hongbo, H. Yudong, Z. Xi, W. Qiang, Z. Jiahua, S. Lu, H. Neel, P.Y. David, W. Suying, G. Zhanhu, Magnetoresistive polyaniline-magnetite nanocomposites with negative dielectrical properties. Polymer 53, 801-809 (2012). https://doi.org/10.1016/j.polymer.2011.12.033

6. A. Khodabakhshi, M.M. Amin, M. Mozaffari, Synthesis of magnetic nanoparticles and evaluation of its efficiency for arsenic removal from simulated industrial wastewater. Iran J. Environ. Health. Sci. Eng 8, 189-200 (2011) 
7. A. Melanie, P. Jerome, P. Olivier, B. Daniel, Enhanced adsorption of arsenic onto magnetic nanoparticles: As(III) as a probe of surface structure and heterogeneity. Langmuir 24, 3215-3222 (2008). 10.1021/la702998x

8. I.Z. Anastasios, A.K. Ioannis, Recent arsenic-contaminated ground waters. Environ. Int. 31, 213-219 (2005)

9. R.C. Ganga, S. Priya, K. Arun, S.K. Mehta, M. Suman, U. Ahmad, Adsorption studies of cationic, anionic and azo-dyes via monodispersed $\mathrm{Fe}_{3} \mathrm{O}_{4}$ nanoparticles. J. Nanosci. Nanotechnol. 13, 32403245 (2013). 10.1166/jnn.2013.7152

10. L. Ruijiang, L. Yi, S. Xiangqian, Y. Xinchun, C. Xuewen, G. Yingying, Adsorption Kinetics and isotherms of arsenic $(V)$ from aqueous solution on to $\mathrm{Ni}_{0.5} \mathrm{Zn}_{0.5} \mathrm{Fe}_{2} \mathrm{O}_{4}$ nanoparticles. J. Nanosci. Nanotechnol. 13, 2835-2841 (2013). 10.1166/jnn.2013.7392

11. X.B. Fang, Z.Q. Fang, P.K.E. Tsang, W. Cheng, X.M. Yan, L.C. Zheng, Selective adsorption of $\operatorname{Cr}(\mathrm{VI})$ from aqueous solution by $\mathrm{EDA}-\mathrm{Fe}_{3} \mathrm{O}_{4}$ nanoparticles prepared from steel pickling waste liquor. Appl. Surf. Sci. 314, 655-662 (2014). 10.1016/j.apsusc.2014.06.191

12. H. Tao, Y. Chao, W. Jide, N. Chunge, S. Xintai, R. Xuehui, Facile additive-free synthesis of iron oxide nanoparticles for efficient adsorptive removal of Congo red and $\mathrm{Cr}(\mathrm{VI})$. Appl. Surf. Sci. 292, 174-180 (2014). https://doi.org/10.1016/j.apsusc.2013.11.108

13. Y. Guide, T. Lin, L. Xiaoxia, Z. Guangming, C. Ye, W. Xue, Z. Yaoyu, L. Sisi, F. Yan, Z. Yi, Cd(II) removal from aqueous solution by adsorption on a-ketoglutaric acid-modified magnetic chitosan. Appl. Surf. Sci. 292, 710-716 (2014). 10.1016/j.apsusc.2013.12.038

14. C. Qi, H. Qinqin, L. Mengmeng, L. Xueting, W. Jin, L. Jianping, The vital role of PANI for the enhanced photocatalytic activity of magnetically recyclable $\mathrm{N}-\mathrm{K}_{2} \mathrm{Ti}_{4} \mathrm{O}_{9} / \mathrm{MnFe}_{2} \mathrm{O}_{4} /$ PANI composites. Appl. Surf. Sci. 311, 230-238 (2014). https://doi.org/10.1016/j.apsusc.2014.05.046

15. Q.L. Jiang, S.W. Zheng, R.Y. Hong, S.M. Deng, L. Guo, R.L. Hu, B. Gao, M. Huang, L.F. Cheng, G.H. Liu, Y.Q. Wang, Folic acid-conjugated $\mathrm{Fe}_{3} \mathrm{O}_{4}$ magnetic nanoparticles for hyperthermia and MRI in vitro and in vivo. Appl. Surf. Sci. 307, 224-233 (2014). https://doi.org/10.1016/j.apsusc.2014.04.018

16. M.J. Chen, H. Shen, X. Li, H.F. Liu, Facile synthesis of oil-soluble $\mathrm{Fe}_{3} \mathrm{O}_{4}$ nanoparticles based on a phase transfer mechanism. Appl. Surf. Sci. 307, 306-310 (2014).

https://doi.org/10.1016/j.apsusc.2014.04.031

17. C.M. Babu, B. Palanisamy, B. Sundaravel, M. Palanichamy, V. Murugesan, A Novel Magnetic $\mathrm{Fe}_{3} \mathrm{O}_{4} / \mathrm{SiO}_{2}$ core-shell nanorods for the removal of arsenic. J. Nanosci. Nanotechnol. 13, 25172527 (2013). 10.1166/jnn.2013.7376

18. C. Lei, X. Hongchuan, F. Yuan, Z. Cong, Z. Feng, C. Xing, Z. Chunhui, L. Xuebing, Application of metal oxide heterostructures in arsenic removal from contaminated water. Journal of Nanomaterials 2014, 793610 (2014). https://doi.org/10.1155/2014/793610. 10 pages.

19. J.W. Park, A.N. Jang, J.H. Song, C.Y. Park, Y.S. Lee, Electronic structure of $\mathrm{Zn}$ doped $\mathrm{Fe}_{3} \mathrm{O}_{4}$ thin films. J. Nanosci. Nanotechnol. 13, 1895-1898 (2013). 10.1166/jnn.2013.6996 
20. L. Xiaolong, Z. Fengqin, M. Chao, S. Elingarami, H. Nongyue, Green Synthesis of Uniform Magnetite $\left(\mathrm{Fe}_{3} \mathrm{O}_{4}\right)$ Nanoparticles and Micron Cubes. J. Nanosci. Nanotechnol. 12, 2939-2942 (2012). $10.1166 /$ jnn.2012.5684

21. B. Zapotoczny, M.R. Dudek, N. Guskos, J.J. Kozioł, B.V. Padlyak, M. Ko'smider, E. Rysiakiewicz-Pasek, FMR Study of the Porous Silicate Glasses with $\mathrm{Fe}_{3} \mathrm{O}_{4}$ Magnetic Nanoparticles Fillers. Journal of Nanomaterials 2012, 341073 (2012). https://doi.org/10.1155/2012/341073

22. L. Méndez-Rodríguez, T. Zenteno-Savín, B. Acosta-Vargas, J. Wurl, M. Imaz-Lamadrid, Differences in arsenic, molybdenum, barium, and other physicochemical relationships in groundwater between sites with and without mining activities. Natural Science 5, 238-243 (2013). 10.4236/ns.2013.52A035

23. L. Kuen-Song, D. Khalilalrahman, L. Yeu-Jye, K. Hua, H. Pei-Ju, Synthesis and Characterization of Porous Zero-Valent Iron Nanoparticles for Remediation of Chromium-Contaminated Wastewater. J. Nanosci. Nanotechnol. 13, 2675-2681 (2013). 10.1166/jnn.2013.7381

24. H.M. Zaki, S. Al-Heniti, U. Ahmad, F. Al-Marzouki, A. Abdel-Daiem, T.A. Elmosalami, H.A. Dawoud, F.S. Al-Hazmi, S.S. Ata-Allah, Magnesium-Zinc Ferrite Nanoparticles: Effect of Copper Doping on the Structural, Electrical and Magnetic Properties. J. Nanosci. Nanotechnol. 13, 4056-4065 (2013). 10.1166/jnn.2013.7434

25. S. Larumbe, C. Gómez-Polo, J.I. Pérez-Landazábal, A. García-Prieto, J. Alonso, M.L. Fdez-Gubieda, D. Cordero, J. Gómez, Ni Doped $\mathrm{Fe}_{3} \mathrm{O}_{4}$ Magnetic Nanoparticles. J. Nanosci. Nanotechnol. 12, 26522660 (2012). 10.1166/jnn.2012.5769

26. R. Deepshikha, K. Rajnish, R.K. Pandey, Structural, Magnetic and Dielectric Properties of $\mathrm{Ni}_{1-}$ ${ }_{x} \mathrm{Zn}_{\mathrm{x}} \mathrm{Fe}_{2} \mathrm{O}_{4}$ ( $\mathrm{x}=0,0.5$ and 1) Nanoparticles Synthesized by Chemical Co-Precipitation Method. J. Nanosci. Nanotechnol. 13, 812-1819 (2013). 10.1166/jnn.2013.7120

27. I. Mizue, T. Hidekazu, K. Tomoji, Preparation of highly conductive Mn-doped $\mathrm{Fe}_{3} \mathrm{O}_{4}$ thin films with spin polarization at room temperature using a pulsed-laser deposition technique. Appl. Phys. Lett. 86, 222504 (2005). https://doi.org/10.1063/1.1942640

28. D. Tripathy, A.O. Adeyeye, Microstructure and magnetotransport properties of $\mathrm{Cu}$ doped $\mathrm{Fe}_{3} \mathrm{O}_{4}$ films. J. Appl. Phys. 103, 07F701 (2008). 10.1063/1.2828504

29. F. Genç, E. Turhan, H. Kavas, U. Topal, A. Baykal, H. Sözeri, Magnetic and Microwave Absorption Properties of $\mathrm{Ni}_{x} \mathrm{Zn}_{0.9-x} \mathrm{Mn}_{0.1} \mathrm{Fe}_{2} \mathrm{O}_{4}$ Prepared by Boron Addition. J. Supercond. Novel Magn. 28, 1047-1050 (2015)

30. T.M. Thi, N.T.H. Trang, N.T.V. Anh, Effects of Mn, Cu doping concentration to the properties of magnetic nanoparticles and arsenic adsorption capability in wastewater. Appl. Surf. Sci. 340, 166172 (2015). https://doi.org/10.1016/j.apsusc.2015.02.132

31. T.M. Thi, V.Q. Trung, D.K. Tung, P.T. Thanh, N.H. Yen, N.M. Lam, Effect of Zn nonmagnetic element doping and a polyvinyl pyrrolidone shell layer on the superparamagnetism and stability properties of magnetic nanoparticles. Jpn. J. Appl. Phys. 60, 025001 (2021). doi.org/10.35848/13474065/abd86d 
32. V. Uwamariya, B. Petrusevski, Y.M. Slokar, C. Aubry, P.N.L. Lens, G.L. Amy, Effect of Fulvic Acid on Adsorptive Removal of $\mathrm{Cr}(\mathrm{VI})$ and $\mathrm{As}(\mathrm{V})$ from Groundwater by Iron Oxide-Based Adsorbents. Water Air Soil Pollut. 226, 184 (2015). 10.1007/s11270-014-2193-5

33. F. Huda, P. Yi-Fong, L. Tsair-Fuh, Effect of Humic Acid on Arsenic Adsorption and Pore. Blockage on Iron-Based Adsorbent. Water Air Soil Pollut. 226, 14 (2015). https://doi.org/10.1007/s11270-0142224-2

34. D.H. Kiril, M. Jasmina, Engineering metal (hydr)oxide sorbents for removal of arsenate and similar weak-acid oxyanion contaminants: A critical review with emphasis on factors governing sorption processes. Science of The Total Environment 598, 258-271 (2017). 10.1016/j.scitotenv.2017.04.108

35. A. Sadia, M.S. Akhtar, Y.S. Kim, O.B. Yang, S. Hyung-Shik, Synthesis and characterization of novel poly(1-naphthylamine)/zinc oxide nanocomposites: Application in catalytic degradation of methylene blue dye. Colloid Polym. Sci. 288, 633-1638 (2010). https://doi.org/10.1007/s00396-0102284-9

36. T.M. Thi, N.T.H. Trang, V.Q. Trung, N.M. Vuong, Properties of poly(1-naphthylamine)/ $/ \mathrm{Fe}_{3} \mathrm{O}_{4}$ composites and arsenic adsorption capability in wastewater. Front. Mater. Sci. 10, 56-65 (2016). https://doi.org/10.1007/s11706-016-0320-5

37. B. Bogdan, G. Andreea, D. Paul, B. Adriana, B. Valentin, Morphological and Structural Analysis of Polyaniline and Poly (o-anisidine) Layers Generated in a DC Glow Discharge Plasma by Using an Oblique Angle Electrode Deposition Configuration. Polymers 9, 732 (2017). doi:10.3390/polym9120732

38. A.W. Paul, O. Clyde, contributors: W.C. Ronnie, P.O. James, Y.S. Yunes (1997) Analytical methods in fine particle technology, Micromeritics Instrument Corporation, Norcross, GA USA, 60-62

39. A.I.A. Sherlala, A.A.A. Raman, M.M. Bello, A. Buthiyappan, Adsorption of arsenic using chitosan magnetic graphene oxide nanocomposite. J. Environ. Manage. 246, 547-556 (2019). https://doi.org/10.1016/j.jenvman.2019.05.117

40. H. Su, Z. Ye, N. Hmidi, High-performance iron oxide-graphene oxide nanocomposite adsorbents for arsenic removal. Colloids Surfaces A Physicochem. Eng. Asp. 522, 161-172 (2017). https://doi.org/10.1016/j.colsurfa.2017.02.065

\section{Figures}




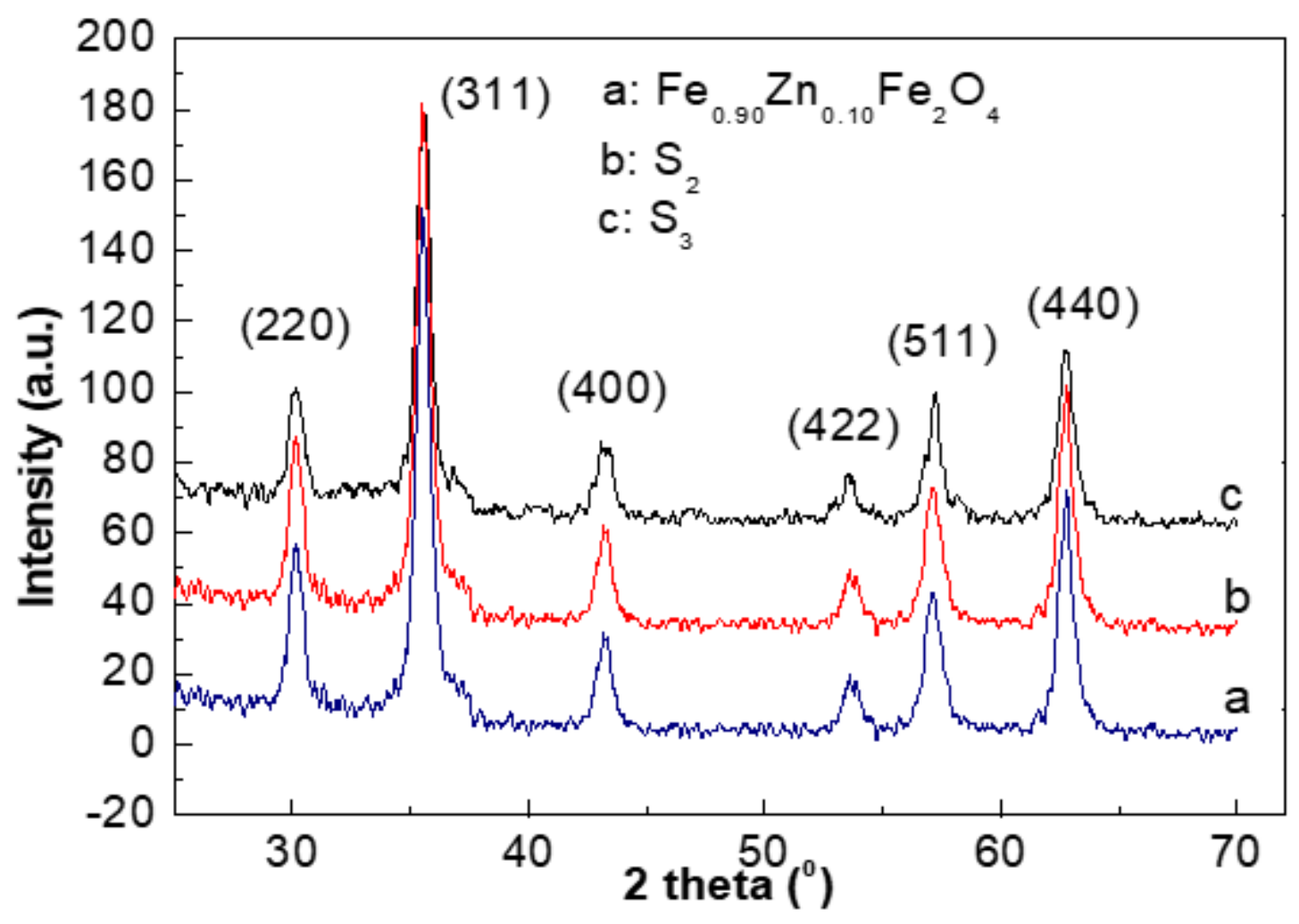

Figure 1

XRD patterns of $\mathrm{Fe}_{0.90} \mathrm{Zn}_{10} \mathrm{Fe}_{2} \mathrm{O}_{4}, \mathrm{~S}_{2}$ and $\mathrm{S}_{3}$

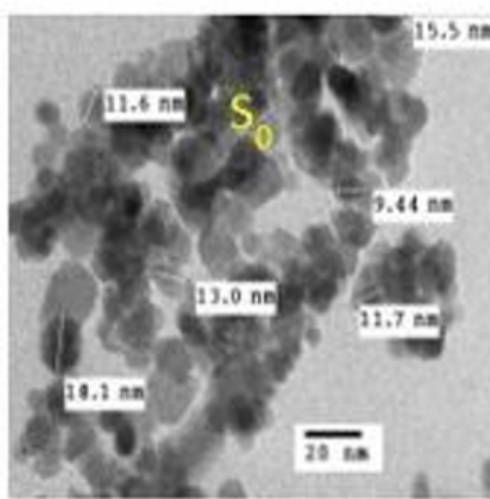

a) TEM of $S_{0}$

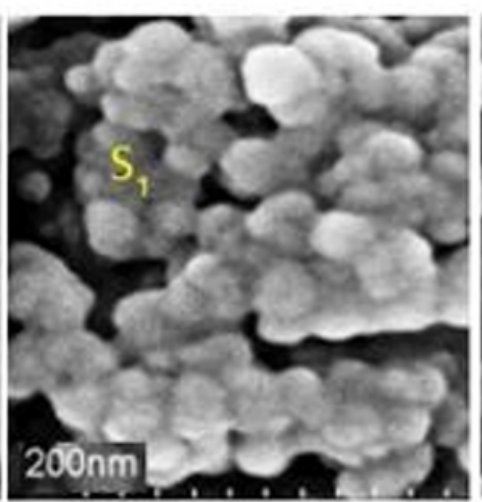

b) SEM of $S_{1}$

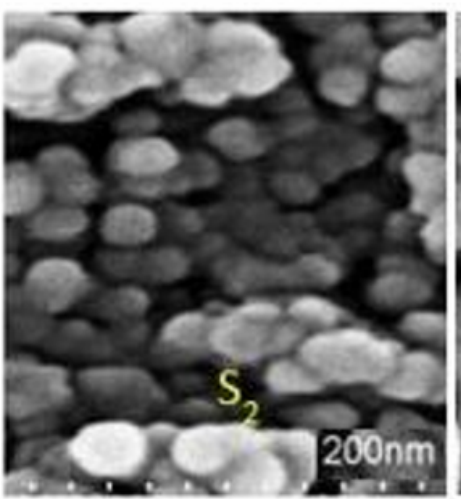

c) SEM of $\mathrm{S}_{2}$

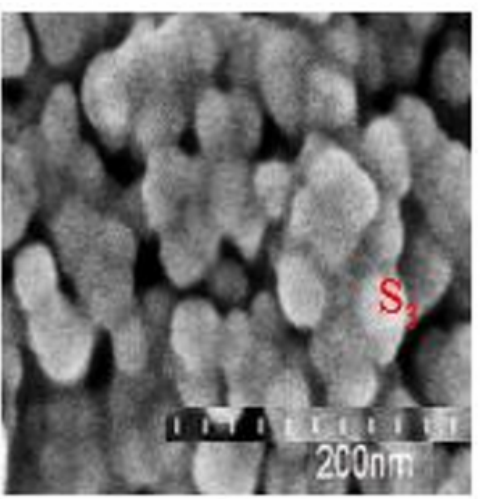

d) SEM of $\mathrm{S}_{3}$

Figure 2

TEM image of $S_{0}(a)$, SEM images of $S_{1}(b), S_{2}(c)$ and $S_{3}(d)$ 

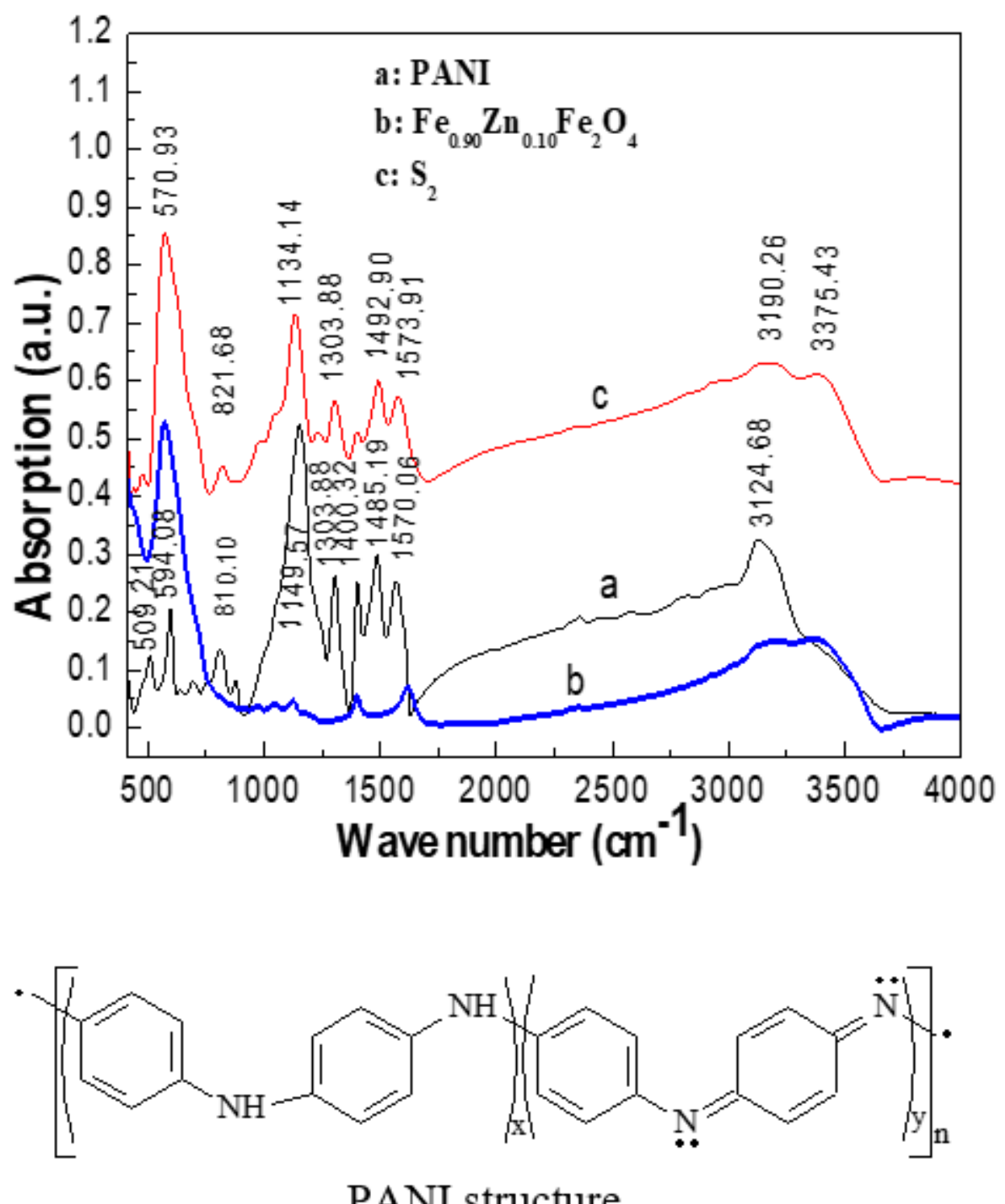

PANI structure

Figure 3

FTIR spectra of samples: a-PANI, b- $-\mathrm{Fe}_{0.90} \mathrm{Zn}_{0.10} \mathrm{Fe}_{2} \mathrm{O}_{4}$, and c- nanocomposite $\mathrm{S}_{2}$ 

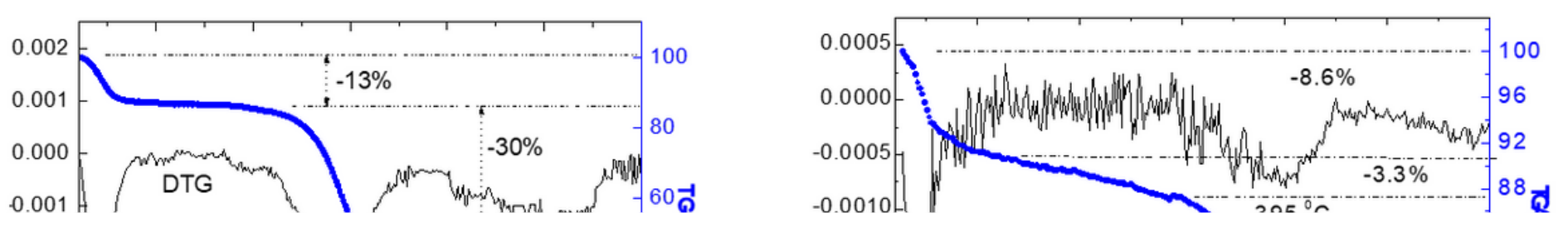

Figure 4

TGA and DTG Analyses of samples: a). PANI, b). $S_{2}$

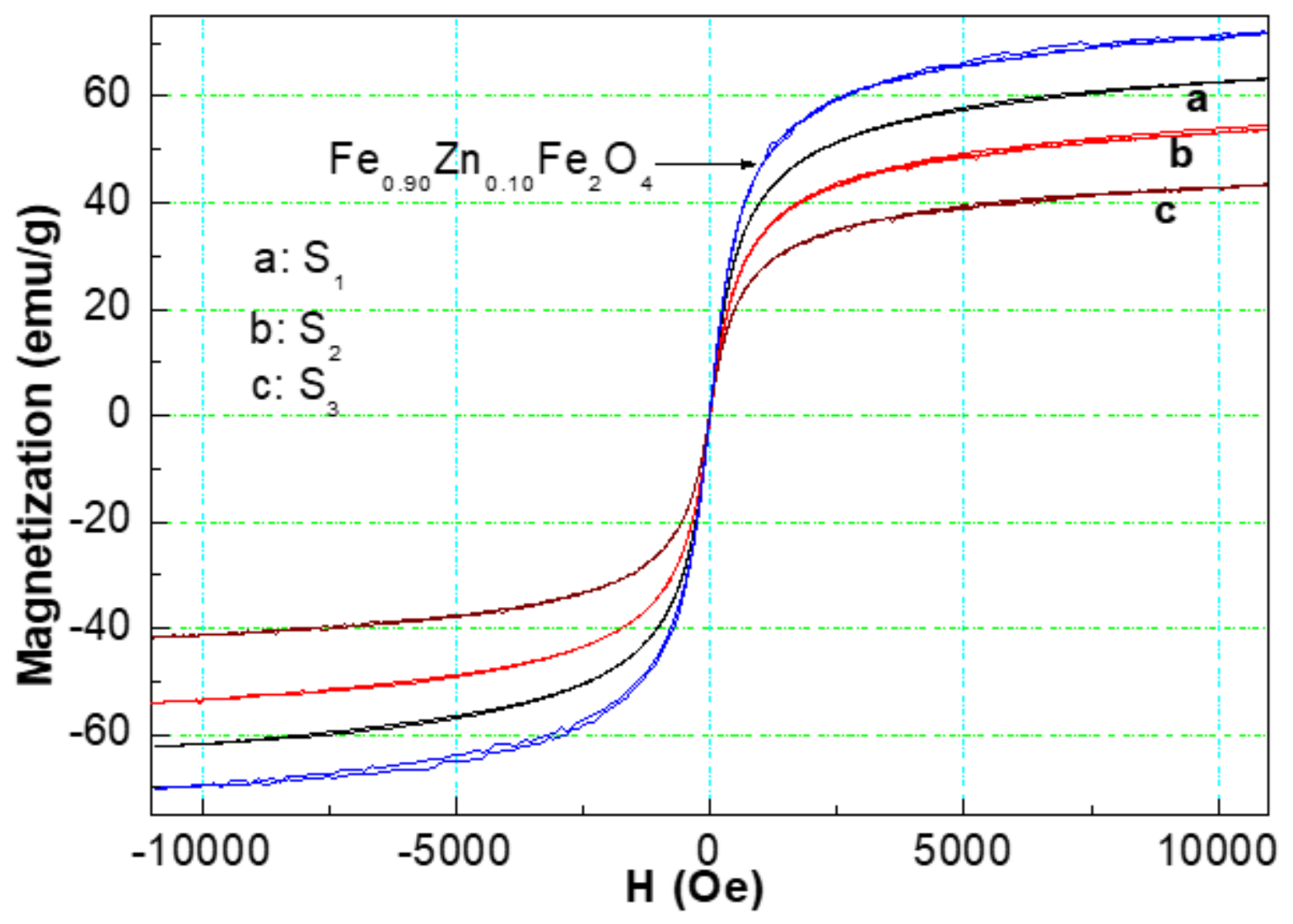

Figure 5

Magnetization curves of $\mathrm{S}_{0}, \mathrm{~S}_{1}, \mathrm{~S}_{2}$ and $\mathrm{S}_{3}$ 

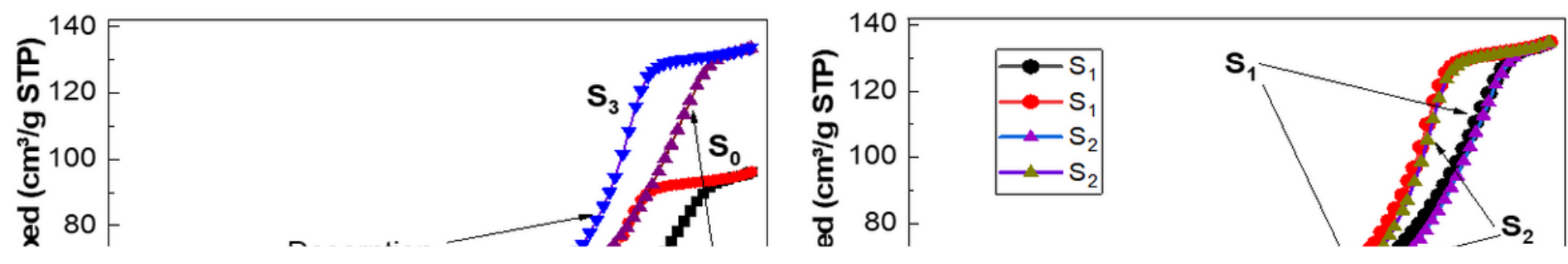

Figure 6

$\mathrm{N}_{2}$ adsorption-desorption isotherm curves of samples

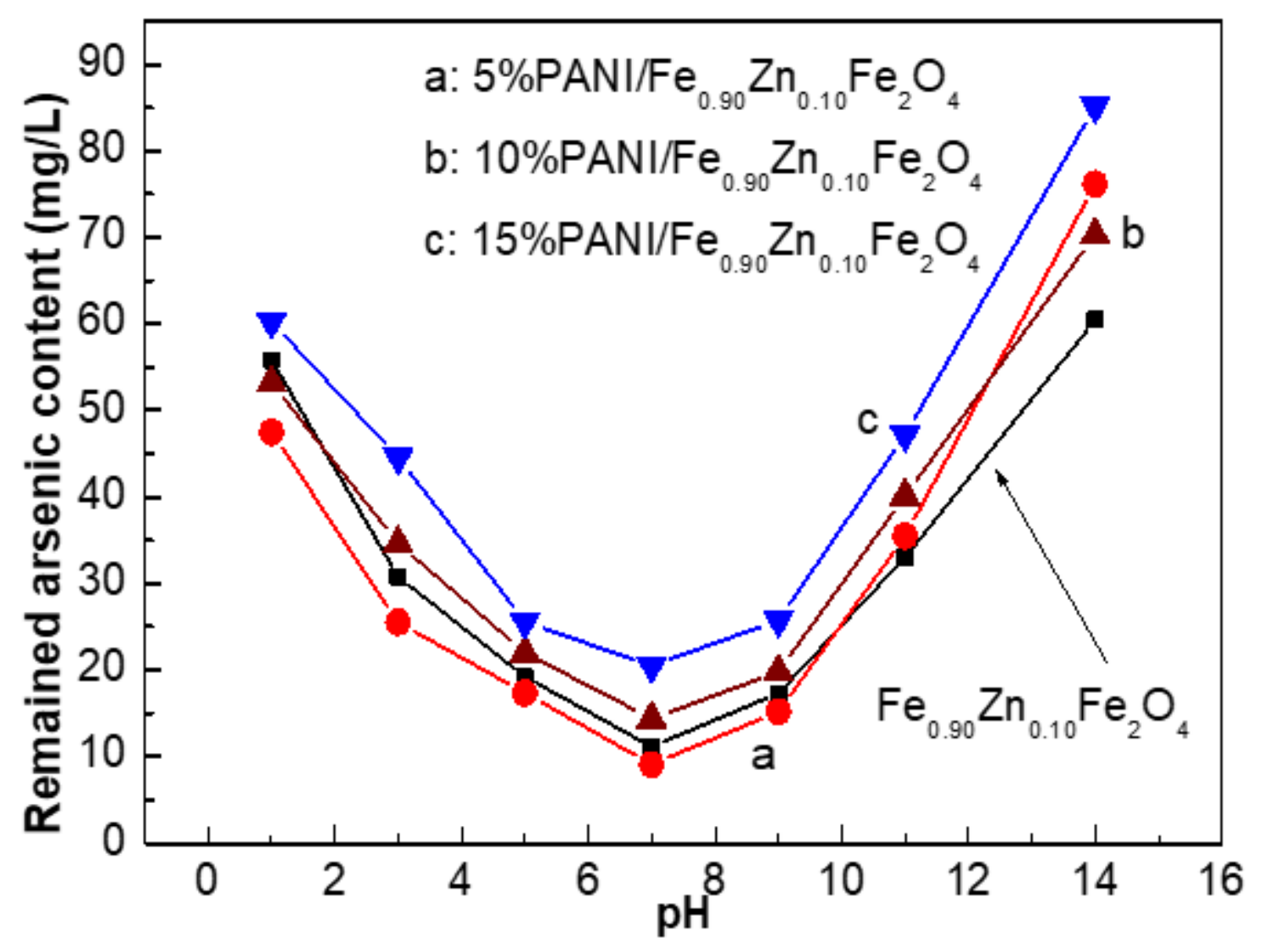

Figure 7 
Remaining arsenic content as a function of $\mathrm{pH}$

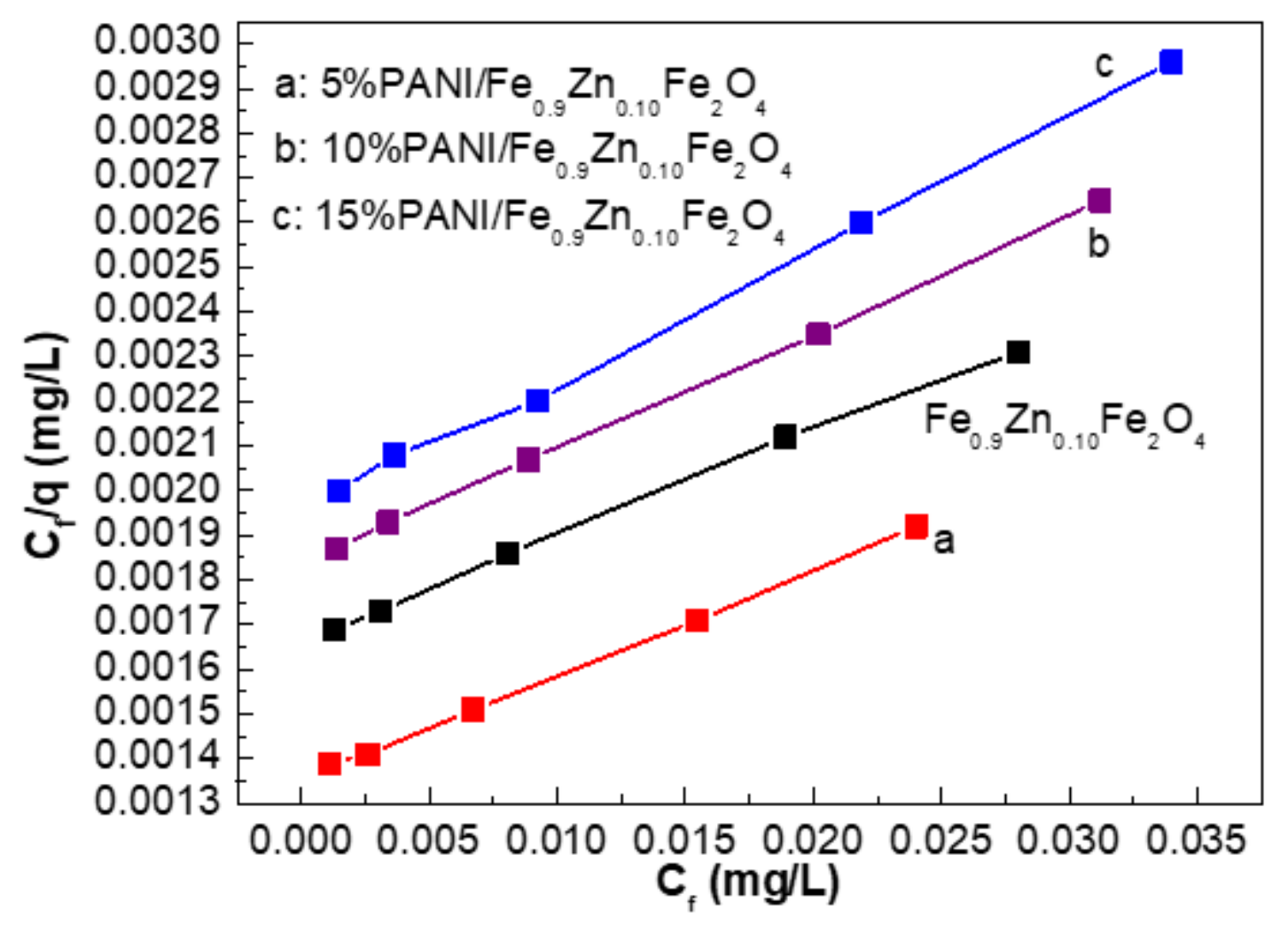

Figure 8

The $\mathrm{C}_{\mathrm{f}} / \mathrm{q}$ dependence on $\mathrm{C}_{\mathrm{f}}$ using adsorbents with different PANI ratios in PANI/Fe $\mathrm{F}_{0.90} \mathrm{Zn}_{0.10} \mathrm{Fe}_{2} \mathrm{O}_{4}$ 